\title{
Transport of Heavy Oil by Applying of Solar Energy
}

\author{
Maral ABDIBATTAYEVA ${ }^{1 *}$, Kylyshbay BISSENOV², Gulzat ASKAROVA, \\ Nurila TOGYZBAYEVA ${ }^{4}$, Gulmira ASSANOVA
}

${ }^{1}$ Al-Farabi Kazakh National University, 71 al-Farabi Avenue, 050040, Almaty, Republic of Kazakhstan

${ }^{2-5}$ Korkyt Ata Kyzylorda State University, 29A Aiteke Bi Street, 120014, Kyzylorda, Republic of Kazakhstan

\begin{abstract}
Crude oil is considered the main source of energy worldwide. Important problems faced by oil transportation methods are spills and unintended releases. Therefore, most technological developments in the field of transportation methods are aimed at reducing emissions, improving efficiency or preventing spills and leaks. Pipeline systems are the safest, most efficient and economical way to transport crude oil. The transportation process suffers from serious problems, such as: asphaltene and paraffin interacting with the structure damages it, pressure drop in the pipes and high energy consumption during pumping. One of the most important economic tasks when transporting oil through a pipeline is to maintain fluidity and reduce the pressure drop along the pipe. This article highlights the latest and most effective development methods that were used to increase the fluidity of crude oil in pipelines, and also examines the possibilities of reducing energy costs for transporting heavy oils and hydraulic resistance of pipelines by creating intermediate solar station devices consisting of a parabolocylindrical concentrator with a tracking system and a solar panel with a converter that increase the safety and environmental friendliness of oil transportation by reducing the risk of accidents. The intermediate solar station uses a renewable energy source and is clean from an environmental point of view, since it does not produce harmful emissions. The use of solar energy as a green alternative to traditional energy carriers makes it possible to increase the productivity of the pipeline by up to $50 \%$, eliminate energy costs during oil transportation.
\end{abstract}

Keywords - Cylindrical parabolic concentrator; heat treatment; heavy oil; oil composition; oil pipeline transportation; properties oil; solar energy

\section{INTRODUCTION}

In the context of climate change, the world is facing a growing need to become more environmentally sustainable by searching for alternative and renewable energy sources that go beyond conventional fossil fuels. Therefore, the use of renewable energy sources, such as wind energy, bio-, hydro-, solar and geothermal energy, is important for achieving the goals of sustainable development worldwide. In the field of solar energy, the most well-known technology is probably photovoltaic cells, but there are several other useful technologies in this field. One of these technologies, which has recently received more attention and which has recently been commercialized, is the concentration of solar thermal energy [1], [2].

This technology is traditionally used for the production of thermal energy; however, this article examines the possibility of using solar thermal energy to reduce the viscosity of oil during transportation through pipelines.

\footnotetext{
* Corresponding author.

E-mail address: maral.abdibattayeva@kaznu.kz 
In the oil industry, solar energy collected and concentrated in a solar power plant can be used in various ways:

1. Photovoltaic systems can convert sunlight into electricity, which, in turn, can be used to power electrochemical cells;

2. PEC or photocatalytic systems can be developed in which electrochemical decomposition reactions are controlled directly by light, without the need to generate electricity separately;

3. Photothermal systems can be used to heat working fluids.

Each of these approaches can be used to produce an environmentally friendly solar fuel that provides 'efficient production, sufficient energy density and flexible conversion into thermal, electrical or mechanical energy'

The world's energy problems would be greatly improved if half of the world's heavy oil and super heavy oil could flow through pipelines. Reducing the viscosity of heavy oils is the key to solving this problem.

Heavy oil and bitumen account for $70 \%$ of the world's discovered petroleum resources. Until now, only a very small fraction of these resources has been extracted, as the extraction methods available for heavy oil and oil sands have traditionally been much more expensive than conventional oil extraction methods.

The cheapest means of oil transport is to transfer oil by main pipelines over long distances. The cost for rail transport is about three times higher and for ocean transport about two times higher than pipelining.

Oil pipeline transportation can be characterized by high throughput, high labour productivity, and low costs. In pipeline transport labour productivity is 5-6 times higher and oil transfer costs are 3.5-4 times lower than in rail transport. However, a significant challenge to pipeline transport is the transfer of heavy oils due to their physicochemical properties. Such oils are complex in composition: they are solutions of solid paraffins, asphaltenes and resins in liquid hydrocarbons. When cooled, paraffins get separated in a wide range of temperatures. The properties of heavy oils deviate from those of Newtonian fluid as soon as the temperature reaches the paraffin crystallization point. Such deviation of properties can be particularly pronounced near and below oil pour point. Thus, the thermal regime is an essential factor determining the technology of transporting paraffin-base (PB) oils.

The industry knows various methods for transporting heavy oil that differ in their approach to reducing the energy consumed for overcoming frictional forces. The most common and reliable method is probably transportation by heated oil pipelines. However, heating furnaces emit significant amounts of harmful substances and the pipeline operator has to pay increased emission fees. Moreover, pipeline accidents connected with heating furnaces result in economic loss and negative social implications. For these reasons, heated oil transportation can be disadvantageous, especially given the increasing PB oil prime cost.

To ensure the efficiency of heavy oil transfer by pipeline, special technologies are needed that can improve the rheological characteristics of transported oils. The rheological characteristics can be seen as additional operation parameters of oil pipelines.

In many parts of the world, heavy crude oil must be transported via pipelines from the production site to refineries or ports. However, transportation by pipeline is very expensive, and sometimes impossible due to the low mobility and high viscosity of crude oil.

Heavy oil is characterized by a low API weight and high viscosity values. Definitions vary from one author to another, but the US Department of Energy determines that heavy oils have an API density of $10{ }^{\circ} \mathrm{C}$ to $20^{\circ} \mathrm{C}$. Oils heavier than $10{ }^{\circ} \mathrm{C}$ are defined as super heavy oils or natural bitumen, if the oil is stationary in reservoir conditions. 
Traditional methods of pipeline transportation of heavy or super heavy oil use heating, mixing of water, and dilution, and, as a rule, the simultaneous use of several methods is required to ensure normal transportation. However, determining the optimal boundary conditions for the transportation of heavy oils is still one of the technical problems.

The authors ' review [3]-[12] highlights the methods currently used to increase the fluidity of heavy crude oil in pipelines by improving rheology, in particular, heating, dilution, oil-inwater emulsion, as well as modernization and annular flow of the core were considered. A method for determining the boundary conditions of heavy oils using combined methods of heating, water mixing and dilution is proposed, and a set of simple diagrams of solutions of boundary conditions for heavy oil is described.

The authors [13] conducted research on the synthesis, use and reuse of magnetic nanospheres of copper ferrite (CFNS) to reduce the viscosity of super heavy oil. CFNS were synthesized using the solvothermic method, resulting in an average particle size of $150 \mathrm{~nm}$. The interaction of CFNS with crude oil was evaluated using asphaltene adsorption isotherms, as well as static and dynamic rheology measurements for two cycles at $25{ }^{\circ} \mathrm{C}$.

The authors [14] have developed a new technology to improve the physical and chemical properties of high-viscosity raw materials, which facilitates processing, increases the share of light fractions and increases their price on the market. Given that it is not yet operating on an industrial scale, a bibliographic review of the achievements in the field of acoustic cavitation technology using ultrasound to improve heavy oil is justified to promote the development of its industrial application by identifying new approaches and guidelines for research in the field of engineering and science.

All the considered methods present some difficulties, since they require large investments in pipeline equipment due to an increase in the transported volume.

At the same time, heated oil transfer by pipeline presents difficulties, especially in winter, due to the high temperature of congelation of HV and PB oils and the deterioration in oil fluidity. Therefore, the problem of preparing such oils for pipeline transportation using effective methods is of major economic importance.

Based on the analysis of literature sources, it can be noted that to date, the transportation of heavy oil, the selection of frozen petroleum products from the storage tank or the discharge from transport tanks in the operating conditions of commodity and raw material parks is difficult, lengthy and in most cases practically not carried out in full due to the lack of technical means. There are many known methods for performing this task, but most often in practical conditions, thermal methods of exposure to frozen petroleum products are used.

In general, it seems appropriate to take decisive measures to reduce the energy intensity of products and losses of already generated energy.

\section{Materials ANd Methods}

In oil transportation, solar-powered heating decreases viscosity and pour point of oil, which improves the conditions for oil pipeline transportation. The significance of this type of oil treatment is confirmed by the innovative patent of the Republic of Kazakhstan No. 22304 [15]. The implementation of the SPHT technology was rather simple and economical. The first stage of this work involved the following tasks:

1. To create a mobile laboratory-scale unit for heat treatment with the use of solar energy of HV and PB oils (including design, manufacturing, installation and commissioning);

2. To experimentally study the thermal effect of heat treatment with the use of solar energy on the rheological properties (viscosity, shear stress, pour point) of the Kumkol oil. 
The unit was designed for heat treatment of oils, having unusual rheological properties, in order to study the thermal effects of solar energy on viscosity, initial shear stress and pour point at different temperatures. The unit must have met the following requirements:

1. To provide the maximum concentration of solar radiation in order to increase the flux density at the receiver;

2. To provide the possibility of heating the oil and controlling the thermal parameters;

3. To ensure the heat treatment of oils by solar energy under various conditions, using a number of new methods for intensifying this process;

4. To control the change in the rheological properties of oil before and after the heat treatment.

The developed technology aimed to increase the pipeline transmission capacity. We also developed several modifications of solar energy concentrators and improved its components.

Both standard and non-standard research methods were used. Studies to justify the use of heat treatment with the use of solar energy in order to improve the rheological properties of oil were carried out on high-viscosity oil, which is difficult to transport by traditional methods. Conducted study to determine the effect of temperature of heat treatment with the use of solar energy to modify the properties of the oil, the analysed composition and properties of oil under thermal processing using solar energy.

When transporting oil using solar energy, a temperature field is formed and the viscosity of the transported oil decreases.

On the basis of the obtained empirical data, using the methods of induction and deduction, theoretical knowledge is formed, which will be theoretically justified, which will ensure the removal of their hypothetical nature and transformation into reliable knowledge.

\section{RESULTS AND DISCUSSION}

There is a method for preparing and pipelining HV oils, which includes heating oil at the inlet to the pipeline and at intermediate stations. However, the need to reheat oil every $25-$ $150 \mathrm{~km}$ along the pipeline adds complexity to the method and fails to profoundly alter the properties of oil. An intermediate station spends 3-5 vol.\% percent of the pumped oil on heating and auxiliaries [16].

In other method for transporting $\mathrm{HV}$ oil, the wall-adjacent annular flow of oil is created and exposed to laser irradiation. However, viscosity reduction and oil transportation in the peripheral stream significantly limit the operational conditions, including the throughput capacity of the pipeline [17].

HV oil can be prepared for pipeline transportation in storage tanks and in the inlet by activating it with laser irradiation at laser power of $0.01 \mathrm{~W}$ or higher and exposure time of $1 \mathrm{sec}$. or more. At that, laser activation requires expensive devices and entails noticeable operational costs [18].

In the work [19], the potential of steam generation of the solar steam generation system and the potential for introduction into Libyan oil on a scale requiring the use of enhanced oil recovery (EOR) methods were investigated. In the proposed system, parabolic troughs are used as solar collectors. The technology has proven its technical feasibility.

In the article [20], were an economic study of the use of a solar thermal system in some branches of the oil industry is carried out. For conducting such a study and based on the study of various solar thermal systems, the most suitable type was a collector with a parabolic trough. The author presents a solar heating system for crude oil to reduce the viscosity of oil to facilitate its transportation through pipelines. Some aspects of design and operation are described. Natural gas, oil and water are simultaneously contained in crude oil, which must 
be heated during transportation through the pipeline. In order to make the system reliable, modern solar collectors with vacuum tubes made of heat pipes were used in the solar heating system. The practical results of the operation showed that it would be possible to save about $30 \%$ of the average daily consumption of natural gas.

One of the devices that can make a significant contribution to energy savings is an intermediate solar station equipped with parabolocylindrical concentrators with a tracking system and a solar panel with a converter.

The creation of an intermediate solar station for the transportation of high-viscosity oil through the main oil pipeline combines the advantages of local and along-route oil heating devices. At the same time, the heat and radiation balance in the area of the pipeline route is practically not disturbed.

As oil heating points, a solar station is used, which includes a parabolocylindrical concentrator with a tracking system and a solar panel with a converter.

Having analysed the shortcomings and advantages of the available oil transportation methods, we developed an intermediate heliostation, which allows increasing the pipeline transmission capacity by $30-50 \%$ and eliminating energy costs associated with oil pipeline transportation.

The CPC with solar mirrors was the principal device of the intermediate heliostation. The reflectivity of the mirrors was 0.85 . The receiver was a black cylinder in a glass sheath. The CPC was positioned to the south-east for a better absorption of solar radiation. The planar-sectioned CPC consisted of flat mirror facets. The solar energy concentrator focused on the linear pipeline. The receiving surface of the linear pipeline warmed up uniformly if the following conditions were met:

- All the flat mirror facets were positioned on the tangents to one generating parabola and touched to it with their central axis;

- The median line of the receiving surface was positioned on the focal line of the CPC.

Heating of oil and petroleum products in solar stations consists in exposure to solar radiation with a natural different flow density with a significant participation in this process of a parabolocylindrical concentrator that focuses the sun's rays as much as possible, while the pipeline transporting high-viscosity oil and petroleum products is an absorbing and accumulating element. The fundamental difference of this method is the use of direct and scattered radiation, even of low density, by using a solar device equipped with a solar panel, a parabolocylindrical concentrator, a tracking system for the Sun. This ensures a constant direction of the sun's light flux perpendicular to the surface of the mirror of the parabolic concentrator from which the most concentrated rays fall directly on the pipeline.

The electricity generated by the solar panel goes to the electric drive of the parabolocylindrical concentrator and contributes to the rotation of the concentrator together with the tracking system, also to the electric drive of the pump, which serves to replenish the energy spent by the flow to overcome the friction forces, in order to ensure further pumping of oil.

The intermediate solar station provides an energy-saving and environmentally friendly technology for the transportation of high-viscosity oil and petroleum products.

Thus, the transported oil was heated by the reflected sunrays. Such CPC should be installed at several intermediate heliostations of the pipeline (Fig. 1). 


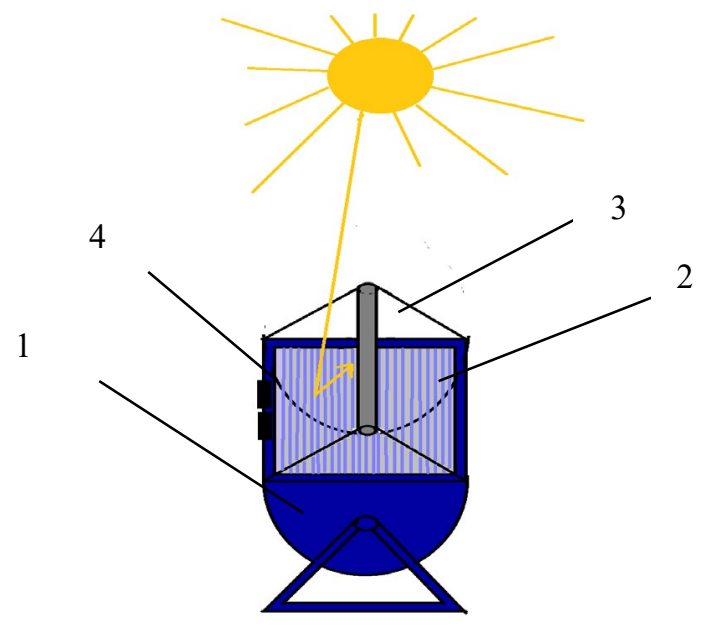

Fig. 1. Cylindrical parabolic concentrator at different Sun angles: $1-$ CPC; 2 - mirror facets; 3 - receiving pipeline; 4 - servosystem.

The main parameters that determine the efficiency of oil transportation through pipelines are their viscosity, pour point and initial shear stress. These parameters, in turn, depend on the natural properties of oil, the amount and ratio of the components that make up their composition of paraffins, asphaltenes, resins and other components, and, of course, on external conditions, mainly on temperature.

The study of the chemical composition and physicochemical properties of oil during heat treatment using solar energy will allow us to more fully characterize the changes that occurred after this type of exposure in the oil of the Kumkol field.

\subsection{Properties of the Studied Oil}

The Kumkol oil was chosen for this research, and most of the experimental work was carried out at the Kumkol oilfield.

Average samples were taken from each sample party during the heat treatment and analyzed for composition and properties as per procedure. Table 1 shows the physicochemical properties of the studied oil. It can be seen that the Kumkol oil is significantly different from other crudes both in composition and properties. Viscosity $(v)$ of Kumkol oil is $8.0 \mathrm{~mm}^{2} / \mathrm{s}$ at $20{ }^{\circ} \mathrm{C}$. The pour point $\left(\mathrm{T}_{3}\right)$, which is an important transportation parameter, is $+13.5{ }^{\circ} \mathrm{C}$. Such parameters as flash point $\left(\mathrm{T}_{\mathrm{B}}\right)$ and saturated vapor pressure $\left(\mathrm{P}_{\mathrm{H}}\right)$ should also be noted. Such properties can be explained by the oil composition. For example, anomalous viscosity and pour point of the Kumkol oil are associated with high paraffin content, and this oil can be categorized highly paraffinic crude.

Thus, the experimental study of such oil can reveal if the proposed method of heat treatment is effective and universal in terms of change in the rheological properties. 
TABLE 1. Properties OF THE KUMKOL OIL

\begin{tabular}{|c|c|c|}
\hline No. & Property & Value \\
\hline 1. & Density, $\rho\left(\mathrm{g} / \mathrm{cm}^{3}\right)$ & 0.824 \\
\hline 2. & Kinematic viscosity $\left(\mathrm{mm}^{2} / \mathrm{s}\right)$ at $20^{\circ} \mathrm{C}$ & 8.0 \\
\hline 3. & Pour point, $\mathrm{T}_{3}\left({ }^{\circ} \mathrm{C}\right)$ & +13.5 \\
\hline 4. & $\begin{array}{l}\text { Flash point } \\
\text { in closed cup }\left({ }^{\circ} \mathrm{C}\right) \\
\text { in open cup }\left({ }^{\circ} \mathrm{C}\right)\end{array}$ & $\begin{array}{l}+8 \\
+15\end{array}$ \\
\hline 5. & $\begin{array}{l}\text { Saturated vapor pressure }(\mathrm{kPa}) \\
\text { at } 37.5^{\circ} \mathrm{C} \\
\text { at } 50.0^{\circ} \mathrm{C}\end{array}$ & $\begin{array}{l}22.250 \\
36.085\end{array}$ \\
\hline 6. & Shear stress, $\tau$ (pa) at $20^{\circ} \mathrm{C}$ & 9.50 \\
\hline 7. & $\begin{array}{l}\text { Chemical composition: } \\
\text { a) paraffins (wt.\%) with melting point at } 49{ }^{\circ} \mathrm{C} \\
\text { b) asphaltenes (wt.\%) } \\
\text { c) silica-gel resin (wt.\%) } \\
\text { d) sulphur (wt.\%) } \\
\text { e) nitrogen (wt.\%) } \\
\text { f) chloride salts (mg/l) } \\
\text { g) acid number (mg KOH/g) }\end{array}$ & $\begin{array}{l}14.26 \\
1.10 \\
7.5 \\
0.235 \\
0.02 \\
1263 \\
0.0045\end{array}$ \\
\hline
\end{tabular}

\subsection{Influence of Temperature Regime on Properties of Oil}

Temperature is probably the main parameter that oil viscosity and hence the efficiency of oil transportation may depend on. Thus, the currently available methods of en-route oil heat treatment are based on the standard temperature specification, considering the oil cooling rate during the subsequent pumping. It is usually recommended to introduce with depressant after heating the oil to $50-70{ }^{\circ} \mathrm{C}$, since these conditions increase with depressant activity. It has not been found yet what the optimum temperature of oil exposed to solar-powered heating should be to reduce viscosity to the minimum. It can only be assumed that it is easier to achieve a 'mature' treatment at a relatively high temperature (above $40-50{ }^{\circ} \mathrm{C}$ ), when oil has a low viscosity and a high fluidity. On the other hand, after the oil temperature decreases and the drusy structures (dendrites) get formed, one can only expect that the heat treatment destroys them and decreases viscosity. In case of such complex systems as oils, it is necessary to experimentally establish the optimum heat treatment temperature and then to determine the general dependence of the rheological properties on the temperature.

The temperature regime for the experiments was chosen:

- Firstly, based on the pour point. To make oil fluid enough to be pumped into the receiving pipeline above the $\mathrm{CPC}$, the temperature should be several degrees above the pour point. For the Kumkol oil, the heating temperature should be at least $20{ }^{\circ} \mathrm{C}$;

- Secondly, taking into account such an important factor as the change in viscosity at a certain temperature. Fig. 3 shows the dependence of kinematic viscosity of the studied oil on the temperature: starting at a certain temperature (about $40{ }^{\circ} \mathrm{C}$ ), viscosity 
remains constant while the temperature keeps increasing (the curve is nearly parallel to the abscissa axis). This means that after the dilution of paraffins and other phase transformations, the oil acquires a stable equilibrium state. Below these temperatures, viscosity rises sharply. This 'transition' state is associated with paraffin crystallization and formation of a spatial network. If the temperature decreases more, the oil solidifies. To determine the optimum heat treatment temperature, it is necessary to carry out experiments starting at low temperatures (while the oil is still fluid though), at which the complex processes leading to oil congelation occur, and at higher temperatures (above $30-40^{\circ} \mathrm{C}$ ), at which the system is rheologically stable.

These considerations formed the basis for the experimental temperature regime. The dependence of viscosity on the temperature up to $60{ }^{\circ} \mathrm{C}$ was studied at an interval of $10{ }^{\circ} \mathrm{C}$ (Fig. 2).

The treatment of oil included:

1. Intensive mixing of oil, i.e. mechanical treatment, before feeding it into the receiving pipeline above the $\mathrm{CPC}$ in order to remove clots and average the sample;

2. Heating the oil to the required temperature;

3. Heat treatment using solar energy the required temperature.

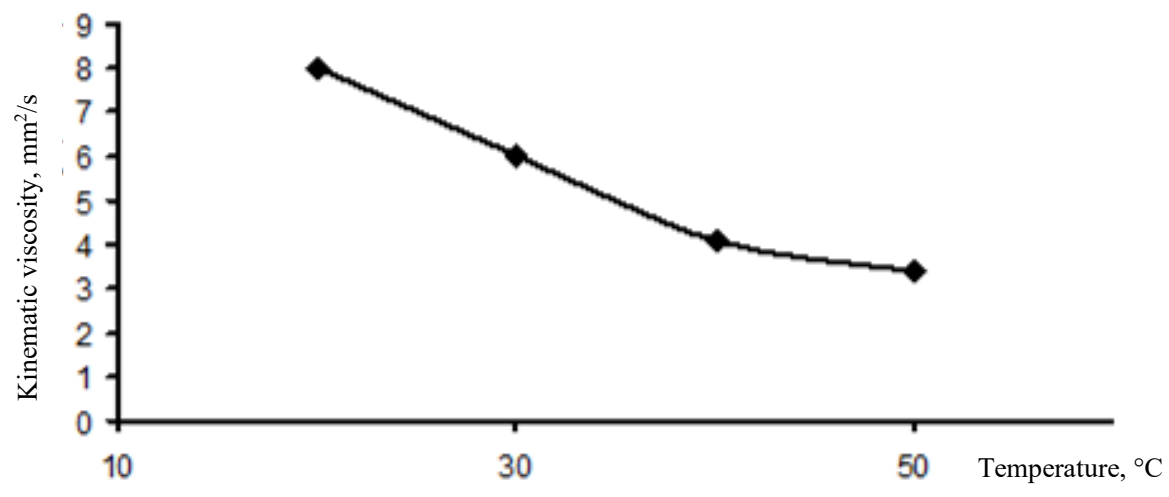

Fig. 2. Dependence of Kumkol oil viscosity on temperature.

The studied oil was exposed solar-powered heating during daylight and at a certain temperature; after that a sample was taken for analysis. Such procedure makes it possible to clearly distinguish the thermal effect on the oil properties, considering the previously established initial parameters of the oil. The experiments were carried out under the constant conditions:

- The time of heat treatment - during the daylight hours;

- Working pressure applied to the CPC $-0.5 \mathrm{MPa}$.

The parameters (temperature and viscosity) of the oil flow were determined experimentally. Fig. 3 shows the oil heating dynamics. The temperature was measured through a thermowell installed in the receiving pipeline. It was found that solar energy can be used in oil pipeline transportation since the oil was heated up to $75^{\circ} \mathrm{C}$. Heating furnaces used in oil fields provide the same temperature.

The thermal effect on the rheological properties of oils was evaluated by the change in kinematic viscosity and pour point. The change in viscosity generally depends on the oil composition and properties. To determine viscosity of the studied oil (both before and after the heating), we used a rather common flow time test (Figs. 4-6). Table 2 shows the flow 
time test results at various temperatures. At that, Table 2 presents relative viscosity that is expressed by the ratio of viscosity of untreated oil to viscosity of heat-treated oil, calculated under the same conditions [21]-[28].

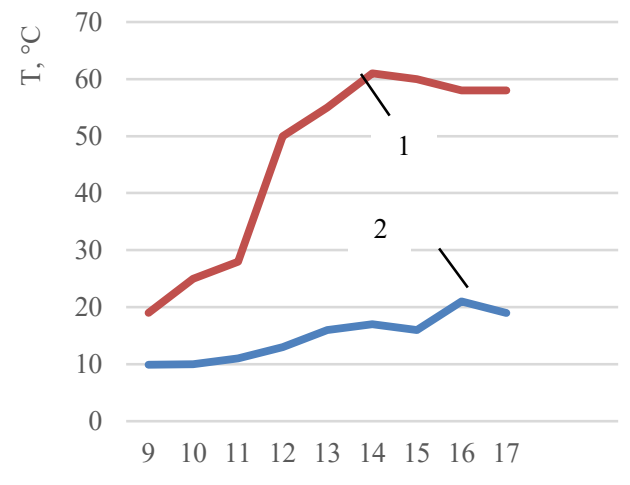

Time, h

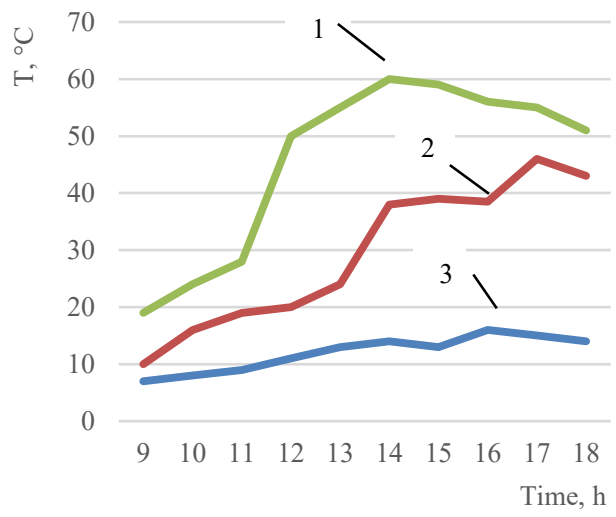

(b)

(a)

Fig. 3. Oil heating dynamics in (a) summer and (b) spring; a) 1-temperature of the oil, 2 - ambient temperature; b) 1 temperature of the oil (with depressant); 2 - oil temperature from the pre-discharge water Installation (PDWI-2) output (without depressants); 3 - ambient temperature.

\section{TABle 2. Change In OIL Viscosity at DifFERENT TeMPERATURES OF THEIR HeAt TREATMENT} WITH THE USE OF SOLAR ENERGY

\begin{tabular}{cllll}
\hline \multirow{2}{*}{ Kumkol oil } & \multicolumn{2}{c}{ Temperature, $\mathrm{T}\left({ }^{\circ} \mathrm{C}\right)$} & \multicolumn{2}{c}{ Kinematic viscosity $\left(\mathrm{mm}^{2} / \mathrm{s}\right)$ before and after heat treatment } \\
\cline { 2 - 5 } & & before & after & rel.\% \\
\cline { 2 - 5 } & 20 & 8.0 & 7.4 & 7.5 \\
30 & 6.05 & 5.45 & 9.92 \\
40 & 4.1 & 3.5 & 14.6 \\
50 & 3.4 & 2.8 & 17.6 \\
\hline
\end{tabular}

Further analysis showed that heat treatment of flowing oil instantly decreased viscosity. The efficiency of the thermal effect on viscosity depended on the temperature of heat treatment. At a low temperature $\left(20^{\circ} \mathrm{C}\right.$ for the Kumkol oil $)$ viscosity decreased only by $7-$ $10 \%$ of its original value, while at $40-50{ }^{\circ} \mathrm{C}$ it decreased by $14-18 \%$.

This dependence has a possible explanation [29]. At a low temperature that is close to the pour point, the paraffin crystallization begins and the space lattice is formed. High melting point paraffins determine the number of crystal nuclei, while low melting point paraffins only bind them to the lattice. Accompanying impurities, in particular, resins and asphaltenes also impact the nucleation. The powerful action of the onset nucleation temperature leads to the destruction of crystal nuclei, and resins and asphaltenes present in the oil get easily adsorbed on the newly formed paraffin surface and create a protective layer that prevents crystallization. Gurvich and Lisovsky [30], [31] proved the adsorption of resins and asphaltenes on paraffins. Surfactants, which are adsorbed on the paraffin surface, can also act as natural depressants after the decomposition of crystal nuclei.

As the temperature rises and, correspondingly, the number of paraffin crystal nuclei decreases, the thermal effect on viscosity wanes. The experimental results (Table 3 ) confirm 
this mechanism of the thermal effect on oil viscosity. Table 3 gives the values of density, kinematic and dynamic viscosity, and shear stress, which clearly demonstrate that all the parameters determining the efficiency of oil pipeline transportation improve after heat treatment with the use of solar energy. Table 3 also shows the change in oil properties in the course of treatment. The change in viscosity after heating improves the rheological properties of oil. Dynamic and kinematic viscosities decreased, as well as shear stress; the shear rate for heavy oil decreases first and then remained constant at the changing temperature.

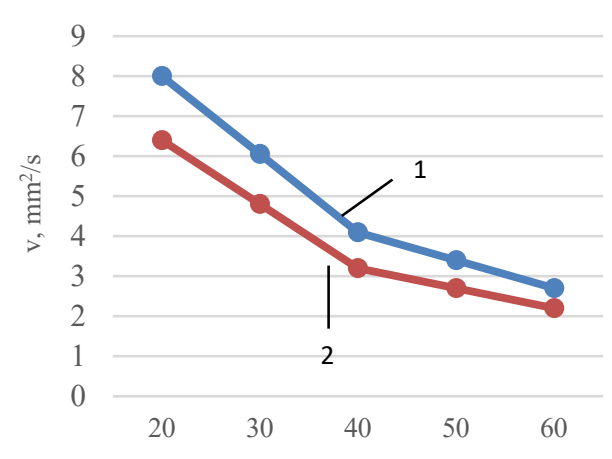

$\mathrm{T},{ }^{\circ} \mathrm{C}$

(a)

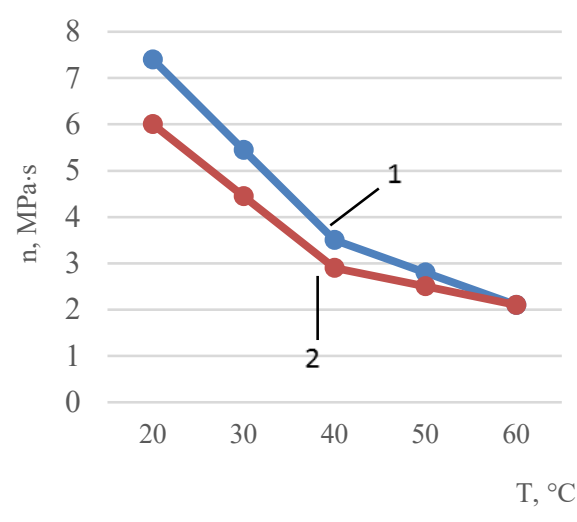

(b)

Fig. 4. Change in the (a) kinematic and (b) dynamic viscosity of oil in summer, where 1 - untreated control sample; 2 solar heated sample.

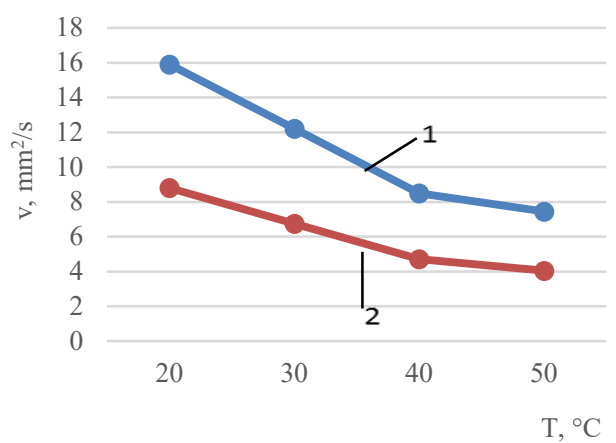

(a)

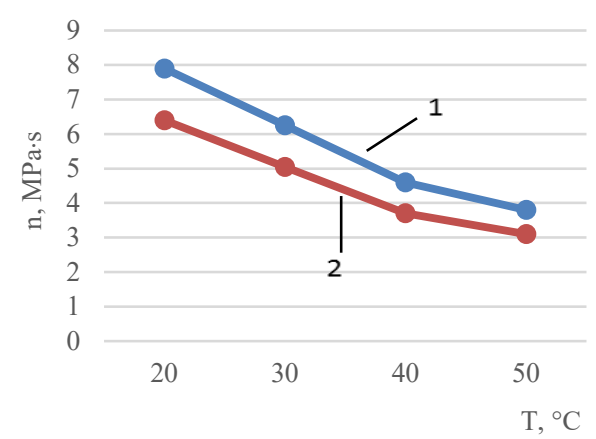

(b)

Fig. 5. Change in the kinematic (a) and dynamic (b) viscosity of oil in spring (with depressant), where 1 - untreated control sample; 2 - solar heated sample. 


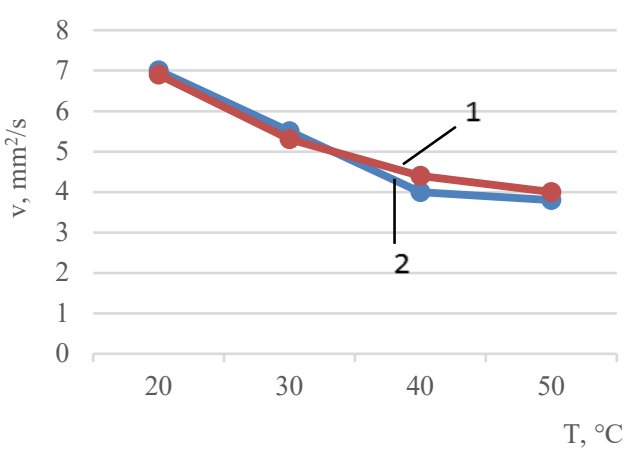

(a)

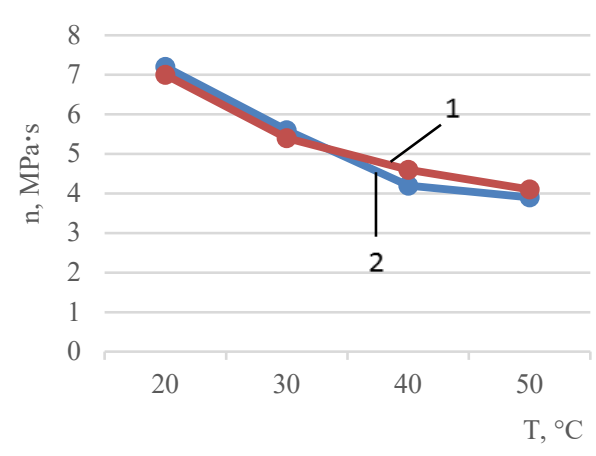

(b)

Fig. 6. Change in the kinematic (a) and dynamic (b) viscosity of oil from the pre-discharge water Installation (PDWI-2) output (without depressants); in spring, where 1 - untreated control sample; 2 - solar heated sample.

The pour point of the studied oil, i.e. the temperature of transition to the non-Newtonian state, was also measured as it is an important characteristic for oil transport operations. The measurement results (Table 3) show that SPHT, even at a low temperature, decreased the pour point by $6-10{ }^{\circ} \mathrm{C}$, while with a rise in treatment temperature the pour point decreased by $3{ }^{\circ} \mathrm{C}$. This dependence matches that of viscosity: the lower the treatment temperature is, the more the pour point decreases. A possible explanation for observed dependences the might be that the processes of viscosity increase and subsequent congelation of oil are interrelated, although there is no direct functional dependence. As already noted, as the ambient temperature falls, the crystal nucleation of paraffins occurs, followed by the formation of the space lattice and the congelation of oil. The heat treatment with the use of solar energy just above the pour point (while the oil is still fluid) destroys the crystal nuclei and drusy structures. The adsorption of surfactants on the surface of broken paraffin lattices prevents further crystallization. As a result, not only viscosity but also pour point is reduced.

Table 3. Pour Point at VArious Temperature Regimes of HeAt Treatment with the Use OF SOLAR ENERGY

\begin{tabular}{llllll}
\hline Oil & \multicolumn{2}{l}{$\begin{array}{l}\text { Pour point }\left(\mathrm{T}_{3}\right) \text { before and after heat treatment } \\
\text { at various temperatures }\left({ }^{\circ} \mathrm{C}\right)\end{array}$} \\
\cline { 2 - 5 } & before treatment & after treatment $\mathrm{T},{ }^{\circ} \mathrm{C}$ & \\
\cline { 2 - 6 } & & \multicolumn{5}{l}{$\begin{array}{l} \\
\end{array}$} & & 30 & 40 & 50 \\
\hline Kumkol & +10.5 & +1 & -1 & -3 & -4 \\
\hline
\end{tabular}

Thus, both processes, i.e. the reduction of pour point and the reduction of viscosity, generally follow the same trend. The findings suggest high efficiency of the studied heating technology. Unlike PPD methods that reduce pour point by $5-6{ }^{\circ} \mathrm{C}$ in average, it does not require preheating of oil to $50-70{ }^{\circ} \mathrm{C}$.

\subsection{Analysis of Oil Composition and Properties of Oil During Heat Treatment with the Use of Solar Energy}

As reported above, heat treatment with the use of solar energy significantly changes viscosity, pour point and shear stress of oil. Since a favourable temperature profile can 
influence the properties of substances, it is interesting to analyse how it affects the composition and structure of the treated oil. Table 4 summarizes the characteristics of oil before and after the treatment.

Table 4. Characteristics of Kumkol Oil Before and After Heat Treatment with the USE OF SOLAR ENERGY

\begin{tabular}{|c|c|c|c|c|}
\hline No. & Property & & Control sample & Treated sample \\
\hline 1 & 2 & & 3 & 4 \\
\hline \multirow[t]{4}{*}{1} & \multirow[t]{4}{*}{ Density, $\rho\left(\mathrm{g} / \mathrm{cm}^{3}\right)$} & $20^{\circ} \mathrm{C}$ & 0.807 & 0.810 \\
\hline & & $30^{\circ} \mathrm{C}$ & 0.804 & 0.805 \\
\hline & & $40{ }^{\circ} \mathrm{C}$ & 0.795 & 0.800 \\
\hline & & $50^{\circ} \mathrm{C}$ & 0.786 & 0.794 \\
\hline \multirow[t]{4}{*}{2} & \multirow{4}{*}{$\begin{array}{l}\text { Kinematic viscosity, } v \\
\left(\mathrm{~mm}^{2} / \mathrm{s}\right)\end{array}$} & $20^{\circ} \mathrm{C}$ & 8.0 & 7.4 \\
\hline & & $30^{\circ} \mathrm{C}$ & 6.05 & 5.45 \\
\hline & & $40^{\circ} \mathrm{C}$ & 4.1 & 3.5 \\
\hline & & $50{ }^{\circ} \mathrm{C}$ & 3.4 & 2.8 \\
\hline \multirow[t]{4}{*}{3} & \multirow{4}{*}{$\begin{array}{l}\text { Dynamic viscosity, } \eta \\
\left(\mathrm{Pa} \cdot \mathrm{s} \cdot 10^{-3}\right)\end{array}$} & $20^{\circ} \mathrm{C}$ & 6.4 & 6.0 \\
\hline & & $30^{\circ} \mathrm{C}$ & 4.8 & 4.45 \\
\hline & & $40^{\circ} \mathrm{C}$ & 3.2 & 2.9 \\
\hline & & $50^{\circ} \mathrm{C}$ & 2.7 & 2.5 \\
\hline 4 & Pour point, $\mathrm{T}_{3}\left({ }^{\circ} \mathrm{C}\right)$ & & +10.5 & -4.0 \\
\hline 5 & Flash point in closed cup $\left({ }^{\circ} \mathrm{C}\right)$ & & +8 & +16 \\
\hline \multirow[t]{3}{*}{6} & \multicolumn{2}{|l|}{ Saturated vapor pressure $(\mathrm{kPa})$} & & \\
\hline & at $37.5^{\circ} \mathrm{C}$ & & 20.410 & 18.47 \\
\hline & at $50^{\circ} \mathrm{C}$ & & 36.085 & 35.63 \\
\hline \multirow[t]{4}{*}{7} & \multirow[t]{4}{*}{ Shear stress, $\tau(\mathrm{pa})$} & $20^{\circ} \mathrm{C}$ & 5.03 & 4.68 \\
\hline & & $30{ }^{\circ} \mathrm{C}$ & 4.75 & 4.32 \\
\hline & & $40{ }^{\circ} \mathrm{C}$ & 4.46 & 3.89 \\
\hline & & $50^{\circ} \mathrm{C}$ & 3.91 & 3.32 \\
\hline \multirow[t]{4}{*}{8} & \multirow[t]{4}{*}{ Shear rate, $\gamma\left(\mathrm{s}^{-1}\right)$} & $20^{\circ} \mathrm{C}$ & 370.7 & 348.9 \\
\hline & & $30{ }^{\circ} \mathrm{C}$ & 362.0 & 342.5 \\
\hline & & $40^{\circ} \mathrm{C}$ & 369.0 & 336.0 \\
\hline & & $50{ }^{\circ} \mathrm{C}$ & 370.5 & 345.0 \\
\hline \multirow[t]{8}{*}{9} & \multicolumn{2}{|l|}{ Chemical composition: } & & \\
\hline & \multicolumn{2}{|l|}{ paraffins (wt.\%) } & 14.26 & 12.03 \\
\hline & \multicolumn{2}{|l|}{ asphaltenes (wt.\%) } & 0.7 & 1.10 \\
\hline & \multicolumn{2}{|l|}{ silica-gel resin (wt.\%) } & 7.5 & 10.0 \\
\hline & \multicolumn{2}{|l|}{ sulphur (wt.\%) } & 0.2 & 0.3 \\
\hline & \multicolumn{2}{|l|}{ nitrogen (wt.\%) } & 0.02 & 0.02 \\
\hline & \multicolumn{2}{|l|}{ chloride salts (mg/l) } & 1263.0 & 1230.0 \\
\hline & \multicolumn{2}{|l|}{ acid number (mg KOH/g) } & 0.0050 & 0.0058 \\
\hline
\end{tabular}

The density of oil increased insignificantly, probably, because the treated oil becomes more homogeneous. The changes in viscosity, pour point, shear stress is discussed above. The flash point increased while the saturated vapor pressure lowered. Apparently, this is due to a change in viscosity of the Kumkol oil. The paraffin content before and after heat treatment with the use of solar energy varies insignificantly. Percentage of resins by weight decreased slightly, 
and that of asphaltenes increased. Resins and asphaltenes are close to unsaturated compounds in their chemical activity. It seems probable that resins turned into asphaltenes after the treatment. Percentage of sulphur by weight increased. Percentage of nitrogen by weight and the content of chloride salts remained unchanged, but the acid number increased. In general, the composition of the studied oil remained nearly the same after heat treatment with the use of solar energy.

Consequently, resins prevent crystallization at decreasing temperature and, thus, reduce viscosity and pour point. Such action of asphalt-resin substances manifests itself when they are present in the composition up to a certain percentage, above which the properties of oil deteriorate. Therefore, at low concentrations resins and asphaltenes act as depressants (substances that help reduce viscosity and pour point), and at high concentrations they enhance viscosity of oil. A high concentration of asphalt-resin substances in PB oils and petroleum products hinder crystallization and shift it towards higher temperatures. It can thus be suggested that, due to the increase in viscosity, the forming paraffin crystals fail to bind into a continuous crystal structure that could otherwise causes anomalous viscosity and yield point.

\section{Conclusion}

The result of our work was the intermediate heliostation equipped with a CPC with servosystem and a solar panel with a converter. The heat-radiating balance in the area where the heliostation was installed remained practically undisturbed. The heliostation was built of domestic components. Working drawings of the heliostation were also developed.

The conditions for transformation and accumulation of solar energy were determined and the feasibility of full or partial use of solar energy in oil pipeline transportation was estimated.

The experimental part of the study determined the optimal parameters of oil transportation modes that can ensure transportability of HV oil.

We devised a scientifically grounded, economically advantageous and energy-efficient solar-powered technology. The heliostation helps to reduce energy costs for the transportation of $\mathrm{HV}$ oil and petroleum products and hydraulic resistance of pipelines.

To further our research, we plan to conduct a semi-industrial testing of the intermediate heliostation at an operating oil pipeline and determine the economic efficiency of the technology more precisely. After the testing, the technology will be introduced into oil transportation with a view to increase safety and sustainability and reducing the risk of accidents.

The implementation of this technology is expected to improve the economic efficiency of oil pipeline transportation since heliostations can replace energy-intensive oil heating stations, boiler plants, direct steam pipelines and return condensate pipelines. The implementation will seek to reduce the cost of solar-powered oil transportation and meet the quality requirements to the transported oil in the domestic and foreign markets.

The present findings might help to solve the problem of using renewable energy for HV oil transportation by pipelining. The intermediate heliostation not produce any harmful wastes and the proposed method of power generation coordinates with the concept of distributed energy production. Our approach has the potential to increase the productivity of pipelines by $3-50 \%$, reduce energy costs and partly eliminate environmental damage associated with oil pipeline transportation. 


\section{REFERENCES}

[1] Sharma A. A Comprehensive Study of Solar Power in India and World. Renewable \& Sustainable Energy Reviews 2011:15(4):1767-1776. https://doi.org/10.1016/j.rser.2010.12.017

[2] Mekhilef S., Saidur R., Safari A. A Review on Solar Energy Use in Industries. Renewable \& Sustainable Energy Reviews 2011:15(4):1777-1790. https://doi.org/10.1016/j.rser.2010.12.018

[3] Jenkins P., et al. Enhanced Oil Recovery by Using Solar Energy: Case Study. Journal of Power and Energy Engineering 2019:7:57-67. https://doi.org/10.4236/jpee.2019.76004

[4] Saniere A., Hénaut I., Argillier J. F. Pipeline Transportation of Heavy Oils, a Strategic, Economic and Technological Challenge. Oil \& Gas Science and Technology - Rev 2004:59(5):455-466.

[5] Abdurahman A. A Study on the Heavy Crude Oil Viscosity Reduction with the Dissolution of Nitrogen and Carbon Dioxide. Thesis. New York: City University of New York, 2015.

[6] Souas F., Safri A., BenmounahA. A review on the rheology of heavy crude oil for pipeline transportation. Petroleum Research 2021:6(2):116-136. https://doi.org/10.1016/j.ptlrs.2020.11.001

[7] Jiaqiang J., et al. Determination of the Transportation Limits of Heavy Crude Oil Using Three Combined Methods of Heating, Water Blending, and Dilution. ACS Omega 2020:5(17):9870-9884. https://dx.doi.org/10.1021/acsomega.0c00097

[8] Soliman E. Flow of Heavy Oils at Low Temperatures: Potential Challenges and Solutions. In Processing of Heavy Crude Oils - Challenges and Opportunities. London: IntechOpen, 2018. http://dx.doi.org/10.5772/intechopen.82286

[9] Yaghi B. M., Al-Bemani A. Heavy Crude Oil Viscosity Reduction for Pipeline Transportation. Energy Sources 2002:24(2):93-102. https://doi.org/10.1080/00908310252774417

[10] Santos R. G., et al. An overview of heavy oil properties and its recovery and transportation methods. Brazilian Journal of Chemical Engineering 2014:31(3):571-590. https://doi.org/10.1590/0104-6632.20140313s00001853

[11] Abarasi H. A review of technologies for transporting heavy crude oil and bitumen via pipelines. Journal of Petroleum Exploration and Production Technology 2014:4:327-336. https://doi.org/10.1007/s13202-013-0086-6

[12] Ibrahim R. I., Odah M. K., Al-Mufti A. An Overview on the Recent Techniques for Improving the Flowability of Crude Oil in Pipelines. Proceedings of the IOP Conference Series Materials Science and Engineering 2019:579:012054 https://doi.org/10.1088/1757-899X/579/1/012054

[13] Mateus, L., et al. Extra-Heavy Crude Oil Viscosity Reduction Using and Reusing Magnetic Copper Ferrite Nanospheres. Processes 2021:9:175. https://doi.org/10.3390/pr9010175

[14] Olaya-Escobar D.-R., et al. Ultrasound Applied in the Reduction of Viscosity of Heavy Crude Oil. Revista Facultad de Ingeniería 2020:29(54):e11528. https://doi.org/10.19053/01211129.v29.n54.2020.11528

[15] Abdibattayeva M. M., et al. Sposob podgotovkii transportirovki po truboprovodu visokovjazkih neftej (Preparing and transportation of high-viscosity oil via pipelines comprises oil treatment and preparation.). Patent Number KZ-A422304. 2006. (in Russian).

[16] Gubin V. E., Gubin V.V. Truboprovodnij transport nefti I nefteproduktov (Pipeline transportation of oil and petroleum products.). Moscow, Nedra, 1982. (in Russian).

[17] Laptev I. I., Bagautdinov G. M. Ustrojstvo dlja snizhenija vjazkosti nefti (Device for reducing the viscosity of oil.). Patent nr. SU 1373970-A1, 1986. (in Russian)

[18] Vykhrest N. Yu., Berishbayev B. E. Method for preparing and transporting highly viscous oils by a pipeline. Patent WO2007067023. 2005.

[19] Zinian He. Application of solar heating system for raw petroleum during its piping transport. Energy Procedia 2014:48:1173-1180. https://doi.org/10.1016/j.egypro.2014.02.132

[20] Abd El Rahman A. M., Nafey A. S, Hassanien M. H. M. Application of Solar Energy Heating System in Some Oil Industry Units and its Economy. Journal of Fundamental Renewable Energy Applications 2017:7:233. https://doi.org/10.4172/20904541.1000233

[21] Abdibattayeva M. M. Ispol'zovaniye solnechnoy energii v neftegazovoy otrasli. Proceedings of the International Scientific and Technical Conference the Role of Universities in the Formation of Innovative Economy 2008:3-6 (in Russian).

[22] Abdibattayeva M. M. Otsenka vozmozhnosti ispol'zovaniya solnechnoy energii pri transportirovke vysokovyazkikh neftey. Proceedings of the 5th International Scientific School of Young Scientists and Specialists Problems of subsoil development in the XXI in the eyes the young 2008:141-144. (in Russian).

[23] Abdibattayeva M. M. Otsenka izmeneniya vyazkosti nefti pri vozdeystvii na neyo teplom solnechnoy energii. Proceedings of the International Congress 'Rational Nature Management and Environmental Safety: Experience and Innovation Petrozavodsk, 2009:9-13 (in Russian).

[24] Abdibattayeva M. M. Pipeline transportation of high viscosity oils using solar energy. Proceedings of the International Scientific Conference 'Universities of the XXI Century: Innovations and New Technologies' 2008:138-141.

[25] Abdibattayeva M. M. Seasonal change in viscosity of oil treated by solar-powered heating. Proceedings of the 6th International School of Young Scientists and Specialists Problems of subsoil development in the XXI in the eyes the young 2009:430-433. 
[26] Abdibattayeva M. M. Preparation and transportation of high viscosity oils by pipeline using solar energy. Proceedings of the International Forum 'Science and Engineering Education without Borders' 2009, V. 2:259-262.

[27] Abdibattayeva M., et al. Complex Oil-containing Waste Treatment by Applying Solar Energy. Environmental and Climate Technologies 2020:24(1):718-739. https://doi.org/10.2478/rtuect-2020-0045

[28] Abdibattayeva M., et al. Purification of Oil-Containing Waste Using Solar Energy. Environmental and Climate Technologies 2021:25(1):161-175. https://doi.org/10.2478/rtuect-2021-0011

[29] Urazgaliev B. U., Belik G. A., Koshebekov J. E. Reologicheskie svojstva tovarnih neftej Embi i Mangishlaka (Rheological properties of commercial oils of Emba and Mangyshlak.). Izvestija Tomskogo Ordena Oktjabrskoj Revoljucii i Ordena Trudovogo Krasnogo Znameni Politehnicheskogo Instituta 1977:300:129-131. (in Russian)

[30] Gurvich L.G.nauchnie osnovi pererabotki nefti (Scientific bases of oil refining.). Moscow-Leningrad: Izdanie soveta neftjanoj promishlennosti, 1925. (in Russian)

[31] Lisovsky L.E. et al. News of University, Oil and Gas Series, 1964. 